\title{
A Wider Europe? The View from Russia, Belarus and Ukraine*
}

\author{
STEPHEN WHITE \\ University of Glasgow \\ JULIA KOROSTELEVA \\ School of Slavonic and East European Studies \\ IAN MCALLISTER \\ Australian National University
}

\begin{abstract}
On the evidence of national surveys conducted between 2000 and 2006, there is a declining sense of European self-identity in the three Slavic post-Soviet republics of Russia, Belarus and Ukraine. Attitudes towards the European Union and the possibility of membership are broadly supportive, but with a substantial proportion who find it difficult to express a view, and substantial proportions are poorly informed in comparison with the general public in EU member or prospective member countries. Those who are better informed are more likely to favour EU membership and vice versa. Generally, socioeconomic characteristics (except for age and region) are relatively poor predictors of support for EU membership as compared with attitudinal variables. But 'Europeanness' should not be seen as a given, and much will depend on whether EU member countries emphasize what is common to east and west or establish 'new dividing lines' in place of those of the cold war.
\end{abstract}

\section{Introduction}

It used to be easy to define 'Europe'. It was bounded by seas and a mountain range. Its peoples spoke Indo-European languages, shared a variety of

\footnotetext{
* Earlier versions of this paper were presented to the VII World Congress of the International Council for Central and East European Studies, Berlin, July 2005, and to the annual conference of UACES at Limerick, Ireland, August to September 2006. We acknowledge the support of the Economic and Social Research Council under grant RES-000-23-0146 to Stephen White, Margot Light and Roy Allison and of the Nuffield Foundation under SGS/32823 to Stephen White and the comments of anonymous referees. 
Christian religions, and transacted their business within a framework that had been established by Roman law. Its origins lay in Christendom, in the Roman Empire and in the Holy Roman Empire that succeeded it and nominally survived until the early nineteenth century. It was divided for most of the century that followed by ideology; but as the iron curtain came down at the end of the 1980s, the political and military alliances of the West began to extend eastwards in a series of enlargements that by 2007 was expected to have taken them as far as the Black Sea. Opinion was sharply divided about whether further enlargement was appropriate. For some, there was simply too great a cultural distance between the existing members and states that might join the union at some point in the future, particularly Turkey. But others still favoured a union that was less exclusively Christian, and which might exercise a beneficent influence on the development of democratic norms in countries in which they were less firmly rooted.

A wider Europe raised some particularly complex issues in relation to the countries of the former Soviet Union. The Baltics were a special case: they had been incorporated during the Second World War in an action that was recognized to have no basis in international law and they resumed their independence in September 1991 while the USSR was still formally in existence; they became members of the EU and of NATO without undue controversy in 2004; and they were very small. But the other former Soviet republics presented more serious difficulties. They had been part of the Russian, rather than the Habsburg Empire. They were predominantly part of eastern, rather than western Christianity. They spoke Slavic, rather than Romance or Germanic languages. And they had experienced two generations of Soviet rule, which left behind a number of distinctive legacies. Not surprisingly, the Western alliances preferred to suggest co-operation rather than membership: in NATO's case, the Partnership for Peace, launched in 1994, of which Russia, Belarus and Ukraine all became members; in the EU's case, a 'Neighbourhood Policy', approved in 2004, and which incorporated a series of North African and other countries that were likely to constitute the Union's immediate proximity for some time to come, perhaps for ever (Commission, 2004; for a discussion see Smith, 2005).

An abundant literature has focused on virtually every aspect of EU relations with its east European neighbours (see for instance Johnson and Robinson, 2005; Antonenko and Pinnick, 2005; Jacoby, 2005; Timmins and Gower, 2007). Rather less attention has been paid to the development of relations in the other direction, between the former Soviet republics and 'Europe', including not only the development of official policy but also the patterns of public attitudes that underpin those relations, and taking account of the literature of these countries themselves (such as Borko and Danilov, 
2005; Butorina and Borko, 2006; Glukharev, 2006). Do Russians, Belarusians and Ukrainians, for instance, think of themselves as 'Europeans' and what place does 'Europe' occupy within their repertoire of loyalties and identities? What view do they take of the European Union itself and what support do they give to the idea of membership, at least as a hypothetical possibility? Are those views associated (so that self-identifying 'Europeans', for instance, support EU membership more than others)? And do 'Europeans', however defined, have characteristic views on other issues of public policy, such as the planned economy or forms of government?

In what follows we focus more closely on this complex of issues, drawing on a series of national representative surveys in Belarus, Russia and Ukraine conducted at several points in time between 2000 and 2006 (an appendix provides further details). We look first of all at some of the issues that arise in considering the 'Europeanness' of the three Slavic republics, and then examine the distribution of a self-assigned European identity and of views of the European Union across time and across the three countries. We move on to consider the dimensions of 'Europeanness', including knowledge and the social attributes of support for a hypothetical EU membership. Finally, we examine the sources of support for a hypothetical EU membership, taking account of regional differences as well as of other predictors; and in a conclusion, suggest some of the larger implications of our findings. We seek throughout to place our findings in a broader comparative context, and to draw on earlier research that allows us to incorporate a strong diachronic dimension.

\section{Identifying 'Europe'}

Just as the geographical boundaries of 'Europe' have shifted over time (see for instance Hay, 1957; Wolff, 1994; Pagden, 2002), so too there have been shifts in the boundaries of 'Europe in the mind' - the complex of values and shared experience that defines a European identity. Much of this work has centred on the European Union and the populations of its Member States, often using the data conveniently provided by the Eurobarometer (see for instance Duchesne and Frognier, 1995; Herrmann et al., 2004; Buonanno and Deakin, 2004; Bruter, 2005). But a European identity is not the same as an identification with the institutions of the European Union, which is the obvious preoccupation of the Eurobarometer, and even after the incorporation of Bulgaria and Romania, EU Member States account for less than half (44 per cent) of the territory and not much more than two-thirds ( 68 per cent) of the population of Europe as conventionally defined. Our primary focus in this 
article is on the three Slavic states in the eastern part of the continent that are largely or entirely 'European' in their location and cultural attributes, but which are not expected to join the European Union in the near future, if at all.

If ambiguity marks the outer limits of this 'European' cultural space, the same is true of the Slavic republics that now constitute the EU's new 'neighbourhood' (see for instance Neumann, 1996, 1999). Belarusians, Russians and Ukrainians share their Christianity with the rest of geographical Europe. They speak a language that is part of the Indo-European family. They have been part of the European state system since at least the seventeenth century and were allies of the West in two world wars. Their students completed their education at European universities; their nobility, before the revolution, spent their summers in Biarritz, Nice and Baden-Baden, and spoke French more readily than Russian. Their royal houses were interrelated, often through a common German ancestry; Nicholas II of Russia even looked like his English cousin, George V. The Bolsheviks themselves had been a part of the Second International before the war, they modelled their new state on the Paris Commune and took their Marxism from Germany. In turn, they expected to become a member of a wider union of socialist republics, first in Europe and then internationally, as the workers of the world discovered their essential unity.

But there were differences, of both an 'objective' and 'subjective' kind. The Slavic peoples belonged to a distinct sub-group within the IndoEuropean family of languages, with a different alphabet. They belonged to eastern, rather than western Christianity. Their historical experience had not been shaped by Roman law and feudalism, and then by the Renaissance and Reformation, but by a Mongol yoke that had lasted two hundred years. Their nobility was an extension of state power, not a check upon it. Their business community was closely regulated by government, which had itself a substantial role as owner and manager. Their church was governed by a Holy Synod, with a membership selected by the Tsar. And their courts were less independent; trial by jury came later than in Western Europe, and could in any case be set aside in political cases. An elected parliament came later still, after the revolutionary upheaval of 1905; even so it had no direct control over the formation of government, or over two-thirds of state expenditure. Later again, all three republics were a part of the Soviet system from its inception.

There were other divisions that were internal to each of the East European societies. Russia, most obviously, stretched across the globe, with most of its population in geographical Europe but most of its territory outside it. Belarus was predominantly Orthodox, but with a substantial Catholic and - historically - Jewish minority. It was part of Kievan Rus, but was later absorbed within the Grand Duchy of Lithuania, which merged with Poland in the 
sixteenth century; later still, after the partitions, it moved into the Russian Empire (the importance of these origins is emphasized in Snyder, 2003). Ukraine was also Orthodox, but with a substantial [Greek] Catholic, sometimes called Uniate, minority, and very marked differences between a Russified, industrial east and a rural, Catholic west of which a part had been within the Austro-Hungarian Empire and had come under Soviet rule as late as 1939. These different historical experiences in turn became alternative narratives that had no very obvious relationship to the 'facts', but which helped to ground and legitimate the claims of a diversity of different political communities (see for instance Wilson, 2000); the two most important of these communities confronted each other directly in the presidential and parliamentary elections of 2004-07.

Huntington's celebrated thesis about the 'clash of civilizations' was mainly concerned with Christianity and Islam, but it also differentiated between the West and a Slavic-Orthodox civilization centred on Russia. The West, he argued, had a number of features that distinguished it, including individualism, the rule of law, a market economy and the separation of church and state. Orthodox civilization, by contrast, was based on a different tradition in which church and state were closely associated, and it had experienced long periods of foreign domination. Differences of this kind, Huntington suggested, were 'far more fundamental than differences among political ideologies and political regimes', and they marked out a society that had 'little resemblance to those developed in western Europe under the influence of very different forces'. Russia fell entirely within Huntington's Orthodox civilization, but it was a 'torn society', spread across two continents and uncertain if it was European or Asian; Belarus and Ukraine were much more obviously divided, with their western regions a part of western Christianity and their eastern regions much closer to the world of Orthodoxy and Islam (Huntington, 1993, pp. 29-31, 43-4; 1996, pp. 139-40, 159).

Differences of this kind had their expression in a continuing internal debate about whether societies of this kind were essentially European or a distinct civilization of their own. In Russia, this took the form of a confrontation between 'westernizers', keen for Russia to adopt more of the institutions and practices of its European neighbours, and 'Slavophils', who took a disparaging view of the immorality, commercialism and division of the West and believed that Russians and the other Slavic peoples had a different and altogether superior destiny (the development of these views is traced in Duncan, 2000). It was differences of this kind that had separated Mensheviks from Bolsheviks before the Russian revolution, and later Trotsky and more internationally oriented Marxists from Stalin and the nativist tradition; later on they separated Western-oriented liberals such as Russia's first foreign 
minister, Andrei Kozyrev, from those who took a more sceptical view of the West's intentions, including many who were prominent in communist, nationalist and Orthodox circles. 'Westernizers', in their modern form, were likely to favour a closer association with 'Europe' and its institutions, and ideally EU membership; 'Slavophils' were more likely to lean towards central Asia, India and China, and were less ready to accept the West's globalizing mission at face value.

Clearly, no single mode of inquiry is likely to do justice to the complexity of characteristics that we might choose to identify as 'European'. As Cederman (2001, p. 1) has noted, Europe 'belongs to the most elusive and contested entities in today's international system'; indeed as Strath (2002) has argued, although there has been a high degree of agreement about the concept of a European identity, there has been such deep disagreement about its content and meaning that its analytical utility may be questioned. In other work, we have ourselves explored the contribution that can be made by qualitative methods, particularly focus groups, as a means of examining the 'meaning' of identities for participants themselves, and " "why" [they] think or feel the way they do' (Litosseliti, 2003, p. 18; see for instance Allison et al., 2005, 2006). In this article we place ourselves within the rather different quantitative tradition that is reflected in the Eurobarometer and the other survey-based exercises that have been carried out on a pan-European basis over the post-communist period (see Slomczyski and Tomescu-Dubrow, 2006 , for a review); it is only methods of this kind that can establish the distribution of attitudes across national populations, between national populations and over time, although they may not always be the most appropriate for other purposes.

\section{Perceptions of 'Europe'}

We asked, first of all, if our respondents in the three countries thought of themselves as 'Europeans' and to what extent. Our results are set out in Table 1; several conclusions emerge. First of all, there has been a general tendency for European self-identity to decline: most obviously in Russia, more irregularly in Belarus and Ukraine. About half of our Russian and Belarusian respondents in 2000 thought they were at least to some extent 'European', and more than a third of our Ukrainians thought the same; five or six years later the proportions were down to a quarter in Russia and Ukraine, although they were rather higher in Belarus. Moreover, the largest movement of opinion had been towards those who felt they were 'not at all' European, who represented at least half of all of our Russian and Ukrainian respondents 


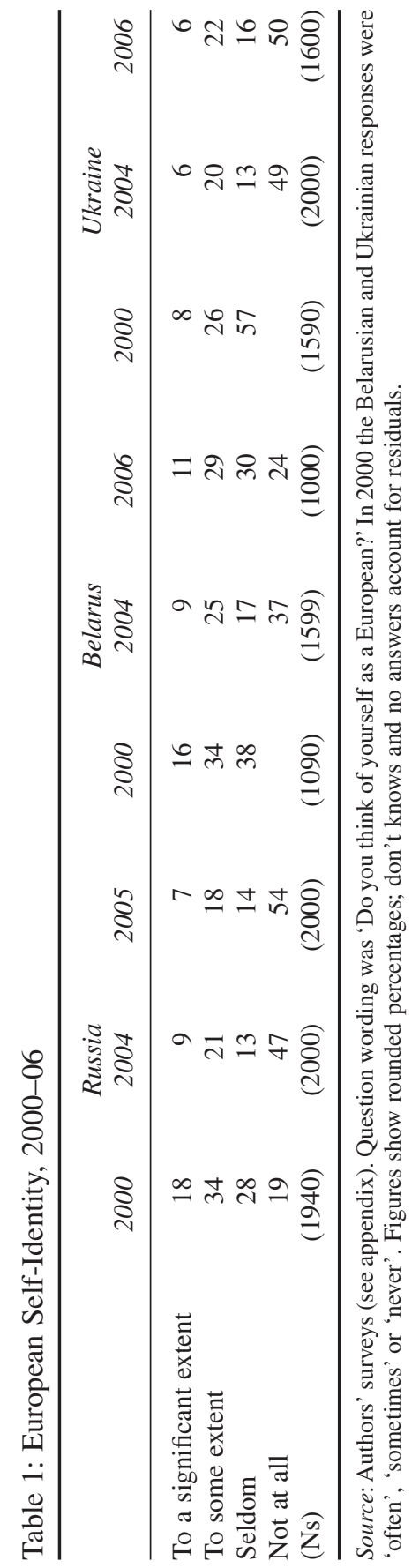


Table 2: European vs Other Self-Identities, 2000-06

\begin{tabular}{lrrrrrr}
\hline & \multicolumn{2}{c}{ Russia } & \multicolumn{2}{c}{ Belarus } & \multicolumn{2}{c}{ Ukraine } \\
& 2004 & 2005 & 2004 & 2006 & 2004 & 2006 \\
\hline European & 10 & 8 & 16 & 20 & 10 & 12 \\
Eurasian & 6 & 3 & 2 & 3 & 2 & 2 \\
Soviet citizen & 13 & 13 & 10 & 12 & 11 & 9 \\
Citizen of my country & 73 & 76 & 72 & 85 & 69 & 68 \\
Citizen of my region & 32 & 29 & 18 & 25 & 27 & 33 \\
From my settlement & 66 & 69 & 65 & 50 & 69 & 64 \\
(Ns) & $(2000)$ & $(2000)$ & $(1599)$ & $(1000)$ & $(2000)$ & $(1600)$ \\
\hline
\end{tabular}

Source: Authors' surveys (see appendix). Question wording was 'Which of the following do you think of yourself to be first of all? And secondly?' Figures show all who gave a corresponding response as their first or second choice, in rounded percentages; don't knows and no answers account for residuals.

in 2005-06 (once again, fewer Belarusians than in the other two countries were likely to take this view). In Russia, in 2000, the largest single group had felt at least 'to some extent' European; by 2005-06, in Russia and Ukraine, the largest single groups were those who felt 'not at all' European, and even in Belarus a majority were more likely to feel 'not at all' or 'seldom' European than to take the opposite view.

Identities, as we have noted, are multiple and polyvalent, not 'givens' that are located outside time and space and no single question is likely to yield a complete and unambiguous set of responses. Accordingly, in later surveys we asked a related set of questions using a wording modelled on the Eurobarometer, which allowed for a first and second choice within a wider spectrum of identities, and which provided responses that could in principle be compared across the entire continent. Our results are set out in Table 2. Again, the main conclusions are clear. Overwhelmingly, in each country, our respondents felt their first identity was as citizen of that country. Almost to the same extent, they identified themselves as citizens of their local area or settlement; regional identities were also popular. But relatively few thought of their identity as a European one, in the first, or even in the second place. Belarusians, who (as we have seen) were more likely to think of themselves as 'Europeans', were also the most likely to identify themselves with a European identity. But the numbers in every case were relatively low; in Russia, fewer chose a 'European' than a 'Soviet' identity a decade and a half after the demise of the USSR.

Across the countries of the European Union, levels of identification with 'Europe' are considerably higher. The Eurobarometer routinely asks if respondents think of themselves as nationals of their own country, or as Europeans, or as nationals of their own country and also Europeans. 
According to the most recent exercise, which was fielded in late 2005, 55 per cent thought they had at least a partly European identity, and rather fewer (42 per cent) thought they had only a national identity (Eurobarometer, 2006, p. 44). Although not precisely comparable, our own figures suggest a primary or secondary European identity that is nowhere more than 20 per cent (in Belarus), as against an identity that is at least partly European among the EU Member States that is nowhere less than 32 per cent (in the UK) and as high as 72 per cent (in Luxembourg). In Bulgaria and Romania, which at the time of the survey had still to join the EU, levels of self-reported European identity were 47 and 59 per cent respectively; even in Turkey, an almost entirely Asian country with no immediate prospect of membership, a substantial 29 per cent thought of themselves as at least partly European - more than twice as many as in Ukraine, a country whose European geographical location and cultural affinity has never been in question.

What, then, about attitudes towards the European Union itself? Whether or not our respondents felt 'European', how did they evaluate the organization within which most of the states in the western part of the continent were economically and politically associated? We set out our results in Table 3. Across the three countries, positive attitudes predominated: by four or five to one, respondents in every case had a 'positive' or 'very positive' image of the European Union, rather than a 'negative' or 'very negative' one. But still more striking is the proportion who were unwilling to express an opinion. In almost every case, they were the largest or equal-largest group of respondents; in every case, they accounted for at least 30 per cent of the total. And although Russians were moving towards a more favourable view of the EU, there was little sign of a movement in the same direction in Belarus and Ukraine (if anything, the opposite). On this evidence, not simply are there relatively low levels of European self-identity in the three Slavic republics that make up the largest part of post-Soviet Europe, there are also relatively large proportions who are not prepared to express an opinion one way or the other about the European Union, although those who do have an opinion are more likely to be positive than negative.

We also asked about membership - even in the case of Yushchenko's Ukraine, not an immediate or medium-term prospect, although the agreement to form a new government of August 2006 reaffirmed the country's long-term Euro-Atlantic aspirations (Financial Times, 5 August 2006, p. 6). We set out our results in Table 4. Again, positive opinions predominated across all three countries, though not quite so decisively: in Russia by about three to one, in Belarus by about two to one, and by rather less in Ukraine although the principle of membership was still supported by a clear plurality. Russians, over time, were becoming more enthusiastic, Belarusians and Ukrainians 


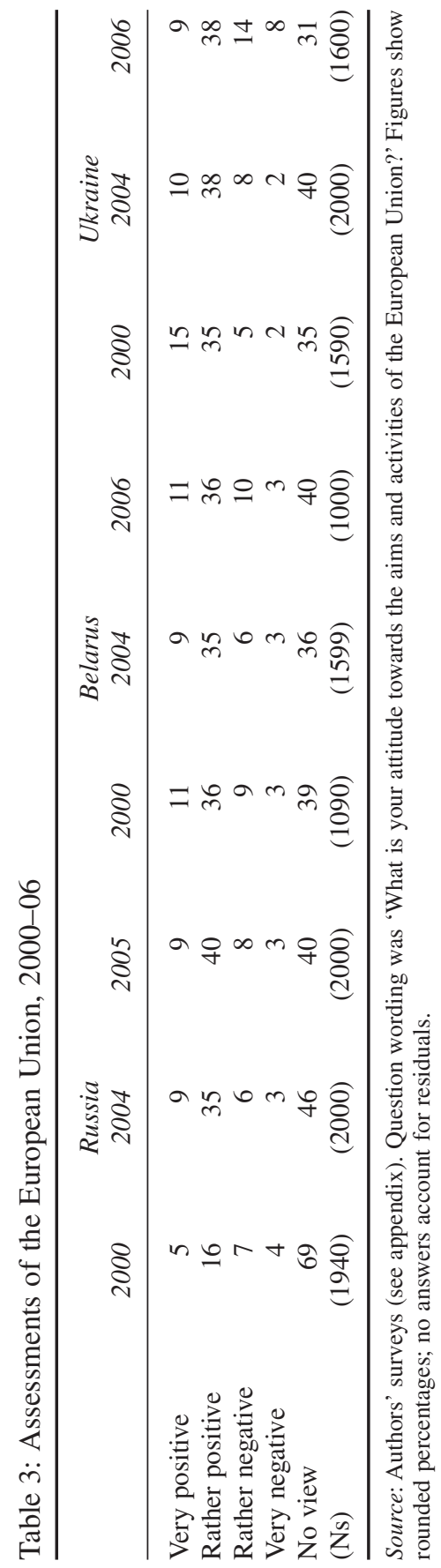




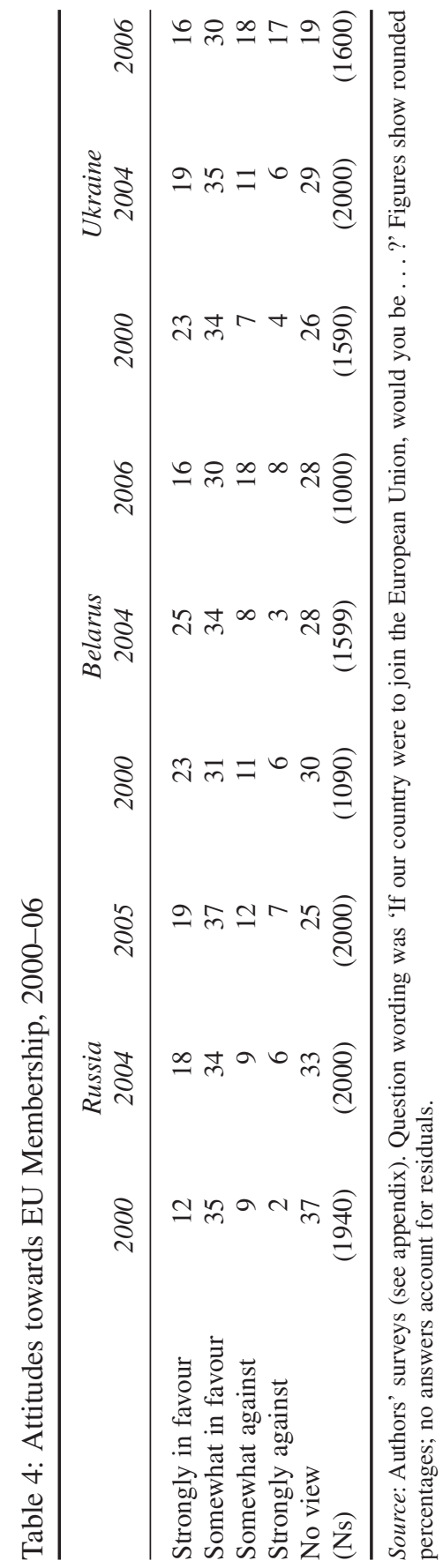


somewhat less so. As before, a substantial proportion in each of the three countries had no opinion. The clearest conclusion of all was perhaps that there was a general stability in attitudes towards EU membership: across the three countries and across a number of years there was substantial support for membership, but also a substantial proportion who found it difficult to make up their mind.

\section{The Dimensions of 'Europeanness'}

Attitudes towards the European Union, as we have seen, are broadly positive across our three countries, but with a substantial and enduring proportion who are reluctant to express an opinion. The same is true of attitudes towards the hypothetical possibility of membership. Uncertainty in such matters need hardly surprise us: none of the three Slavic republics is being considered for admission and they are geographically remote from the EU's original member nations, although not from the ten new Member States that joined in 2004. But it is also likely that high levels of uncertainty are associated with modest levels of knowledge of the EU and of the working of its institutions, not just in 'absolute' terms but as compared with levels of knowledge in the original Member States and those that became members in 2004; and that this is a reciprocal relationship in which the better informed are more likely to be certain in their views (and more positive), and those who are more certain in their views and more positive are likely to be better informed.

How many, for a start, could identify the European Union from a list of four international organizations, one of them entirely fictitious? A plurality in every case identified it as an "economic and political association of the countries of western Europe', which we regarded as the correct answer. But substantial numbers in Russia and Ukraine identified it as 'an association of European countries including our country', with the Council of Europe presumably in mind, and many others chose either 'a military association of the countries of western Europe and North America' (NATO) or 'the European section of the United Nations' (which does not exist). Between a quarter and a third, the second largest group in every case, had no idea (Table 5). We also asked about the location of the EU headquarters, with Brussels as one of the five options available; nowhere did as many as a half identify Brussels correctly, although a fifth would have done so randomly. About a third of our Belarusian and Ukrainian respondents answered both questions correctly, but fewer Russians.

As we had hypothesized, those who were better informed were more likely to express a definite opinion about the EU and the prospect of membership, 
Table 5: Knowledge of 'Europe', 2000-06

\begin{tabular}{|c|c|c|c|c|c|c|c|c|c|}
\hline & \multicolumn{3}{|c|}{ Russia } & \multicolumn{3}{|c|}{ Belarus } & \multicolumn{3}{|c|}{ Ukraine } \\
\hline & 2000 & 2004 & 2005 & 2000 & 2004 & 2006 & 2000 & 2004 & 2006 \\
\hline \multicolumn{10}{|l|}{ What is the EU? } \\
\hline $\begin{array}{l}\text { An association of European } \\
\text { countries, including our } \\
\text { own }\end{array}$ & - & 17 & 16 & - & 9 & 6 & - & 14 & 13 \\
\hline $\begin{array}{l}\text { A military alliance of W. } \\
\text { Europe and N. America }\end{array}$ & - & 6 & 8 & - & 8 & 4 & - & 5 & 9 \\
\hline $\begin{array}{l}\text { A political and economic } \\
\text { alliance of } \mathrm{W} \text {. Europe }\end{array}$ & - & 40 & 39 & - & 48 & 53 & - & 42 & 51 \\
\hline The European section of UN & - & 6 & 8 & - & 5 & 5 & - & 6 & 4 \\
\hline Don't know/No answer & - & 32 & 29 & - & 30 & 32 & - & 34 & 23 \\
\hline \multicolumn{10}{|l|}{ Where is the EU HQ? } \\
\hline Brussels & 31 & 34 & 39 & 34 & 49 & 49 & 27 & 36 & 48 \\
\hline Don't know & 60 & 40 & 50 & 56 & 42 & 42 & 68 & 56 & 37 \\
\hline Both correct & - & 18 & 22 & - & 31 & 34 & - & 21 & 30 \\
\hline One correct & - & 38 & 35 & - & 35 & 33 & - & 36 & 39 \\
\hline Neither correct & - & 44 & 43 & - & 34 & 33 & - & 43 & 31 \\
\hline (Ns) & 1940 & 2000 & 2000 & 1090 & 1599 & 1000 & 1590 & 2000 & 1600 \\
\hline
\end{tabular}

Source: Authors' surveys (see appendix). Question wordings were 'Which of the following is the most accurate characterisation of the European Union?' (this question was not asked in 2000); and 'As you probably know, 25 states of Western Europe have united in the European Union. Do you know in which city the headquarters of the European Union is located?'. Figures show rounded percentages; in the second case no answers account for residuals.

and to be more positive than their counterparts; and those who were more positive were themselves likely to be better informed. For instance, in Russia, 39 per cent were able to identify the European Union as an organization, but 49 per cent of those who felt 'to a significant degree' European were able to do so, and 46 per cent of those who 'strongly approved' of membership. In Belarus, 53 per cent identified the EU correctly, but 66 per cent of those who strongly supported membership; conversely, 17 per cent of the entire sample strongly supported membership, but 21 per cent of those who identified the EU correctly. There were similar results in Ukraine, where 51 per cent identified the EU correctly but 60 per cent of those who 'strongly supported' membership were able to do so. Not surprisingly those who identified the EU correctly were also more likely to identify the city that is its administrative headquarters and vice versa. The better informed, in each of the three countries, the more likely to support membership; and the more likely to support membership, the better informed. 
We have no wish to exaggerate the command of detail that is possessed by ordinary Europeans about the complex framework of which their states are members; nor would it be appropriate to ask exactly the same questions as we put to our respondents in Russia, Belarus and Ukraine, none of which is a member country. Nonetheless, a comparison with the kinds of responses obtained by the Eurobarometer suggests a considerable East-West gap in understanding. Across the EU itself, 58 per cent were aware that the Union did not 'consist of twelve Member States'. A very similar 59 per cent were aware that the President of the EU Commission is not 'directly elected by the citizens of the European Union', and a comparable 58 per cent that the European Parliament is 'directly elected by the citizens of the European Union'. In Russia, Belarus and Ukraine, as we have seen, not even half of our respondents could identify the EU in the most general terms. In the EU member countries, similarly, as many as 94 per cent had seen the EU flag and 95 per cent could identify it correctly (Eurobarometer, 2005, pp. 40-6, 92-3); this compared for instance with Russia, in which not much more than a third of our respondents were able to pick out Brussels as the EU headquarters, although Belarusians and Ukrainians were better informed.

Apart from being better informed, did supporters of EU membership have other characteristics that set them apart from their counterparts? Were they likely to be younger or older, richer or poorer, or in any way distinctive in their attitudes towards the political and economic system? We set out the evidence in Table 6. The attributes of EU supporters, it emerged, were generally very similar across the three countries. Those who favoured membership, for instance, were more likely to be male than female; they tended to be younger than the population as a whole; and they were likely to have higher levels of education, which was obviously consistent with their better levels of knowledge. In Russia and Ukraine, they were also more likely to have higher (self-assessed) incomes. Many of these patterns, however, were asymmetric. Thus, in all three countries males were not only more likely to support EU membership, but also more likely to oppose it. The same was true of Belarusian respondents with a higher education and of urban as compared with rural residents. Similarly, the effects of higher incomes were strong in Russia and Ukraine, but not in Belarus.

There were stronger and more predictable associations with a series of policy positions, some of which are part of the Copenhagen conditions that set out the prerequisites for EU membership. In every case, Belarusians, Russians and Ukrainians who supported membership were also more likely to favour Western-style democracy and to oppose the unreformed Soviet system. EU supporters were more likely to support a market economy than a planned economy of the Soviet type. They were more likely to 'feel European' and 
Table 6: Support for EU Membership by Socioeconomic Characteristics and Policy Preferences, 2004

\begin{tabular}{|c|c|c|c|c|c|c|}
\hline & \multicolumn{2}{|c|}{ Belarus } & \multicolumn{2}{|c|}{ Russia } & \multicolumn{2}{|c|}{ Ukraine } \\
\hline & For & Agst & For & Agst & For & Agst \\
\hline \multicolumn{7}{|c|}{ Socioecon. characteristics } \\
\hline Male & 65 & 13 & 55 & 18 & 60 & 19 \\
\hline Female & 54 & 10 & 49 & 12 & 50 & 15 \\
\hline Under 30 years & 69 & 8 & 59 & 13 & 68 & 11 \\
\hline 60 or older & 42 & 13 & 38 & 15 & 40 & 18 \\
\hline Urban & 63 & 12 & 53 & 16 & 56 & 17 \\
\hline Rural & 52 & 8 & 50 & 11 & 50 & 16 \\
\hline Primary education & 32 & 10 & 35 & 14 & 32 & 16 \\
\hline Higher education & 67 & 14 & 69 & 16 & 70 & 14 \\
\hline Low income & 61 & 10 & 46 & 16 & 45 & 20 \\
\hline High income & 59 & 14 & 61 & 14 & 66 & 16 \\
\hline \multicolumn{7}{|c|}{ Political system preferences } \\
\hline $\begin{array}{l}\text { Favours Western } \\
\text { democracy }\end{array}$ & 81 & 7 & 64 & 12 & 77 & 9 \\
\hline $\begin{array}{l}\text { Favours Soviet system } \\
\text { before perestroika }\end{array}$ & 37 & 21 & 41 & 17 & 32 & 26 \\
\hline \multicolumn{7}{|c|}{ Economic system preferences } \\
\hline $\begin{array}{l}\text { Favours a market } \\
\text { economy }\end{array}$ & 71 & 8 & 59 & 15 & 64 & 14 \\
\hline $\begin{array}{l}\text { Favours a Soviet-type } \\
\text { economy }\end{array}$ & 44 & 17 & 47 & 15 & 46 & 21 \\
\hline \multicolumn{7}{|c|}{ Foreign policy preferences } \\
\hline Feels European & 79 & 8 & 66 & 11 & 79 & 9 \\
\hline Doesn't feel European & 56 & 13 & 49 & 17 & 48 & 22 \\
\hline $\begin{array}{l}\text { Supports NATO } \\
\text { membership }\end{array}$ & 87 & 5 & 74 & 9 & 83 & 7 \\
\hline $\begin{array}{l}\text { Opposes NATO } \\
\text { membership }\end{array}$ & 54 & 22 & 54 & 25 & 40 & 34 \\
\hline Total & 59 & 11 & 52 & 15 & 54 & 17 \\
\hline
\end{tabular}

Source: Authors' surveys (see appendix). Row percentages. Question wording as in Table 4. 'No view' and 'No answer' account for residuals. Cells highlighted in bold show a statistically significant association between the two variables, judged by the values of adjusted residuals (see Miller et al., 2002, pp. 132-3).

very much more likely to favour NATO membership. But were these spurious associations, or did they remain valid when we controlled for other variables? We examine the direct effects of EU membership support in the next section of the article, holding other variables constant, and introduce a regional element that allows us to disaggregate our results across the larger subnational components of three politically diverse societies. 


\section{Predicting Support for EU Membership}

Earlier studies have suggested that in the post-communist region younger age and higher education - in particular - are closely associated with a membership perspective (Haerpfer, 2002, pp. 124-5, 127-8; Caplanova et al., 2004, p. 279, education; Tucker et al., 2002, p. 561, age, but not education). The results of our own cross-tabulations in Table 6 also suggested that a higher level of education, younger age and European self-perception would all be likely to exert a positive and statistically significant effect on support for EU membership. And we expected regional differences to play a significant part in explaining support for EU membership, with those in the western part of the country (for instance) more pro-European than those in the east, and more likely to favour membership. Furthermore, we expected regional differences to be a stronger predictor of support for EU membership in Ukraine, with its strongly self-conscious regionalism, and less so in Belarus and Russia (which have a greater degree of cultural homogeneity). In Russia our distinction was between its European residents, west of the Urals and the remainder. Finally, we expected that better knowledge of the EU and a higher level of identification with 'Europe' would have a positive and statistically significant relationship with the level of support for prospective membership with effects that were likely to be particularly marked in Belarus, given that Belarusians were better informed than other respondents and more likely to think of themselves as Europeans.

We consider this complex of factors in Table 7, in which we examine the extent to which the variables we have identified help to explain support for EU membership, with other factors held constant. We exclude from our analysis such variables as support for a Western-style political system, support for a market economy and for NATO membership, given that the relationship between these variables and support for EU membership is bidirectional. ${ }^{1}$ Multinominal logistic regression is used in all three cases to predict support for EU membership.

The explanatory power of all three models was satisfactory, with our predictors, taken together, explaining from a quarter to a third of the variation in the dependent variable. In all three countries socioeconomic characteristics, apart from age and geographical location, were weak predictors of support for EU membership, with inconsistent effects that varied across the

\footnotetext{
${ }^{1}$ A bidirectional relationship implies that, for instance, as much support for EU membership can be predicted by support for a market economy as vice versa. This problem can empirically be resolved by a two-stage least-squares methodology incorporating the use of instrumental variables (for a discussion of the relevant tests see Gujarati, 1995). The absence of appropriate instrumental variables that could be highly correlated with each of the endogenous regressors but uncorrelated with support for EU membership, however, makes it difficult to carry out an analysis of this kind.
} 


\begin{tabular}{|c|c|c|c|}
\hline & Belarus & $\begin{array}{c}\text { Parameter estimates } \\
\text { Russia }\end{array}$ & Ukraine \\
\hline \multicolumn{4}{|c|}{ Socioeconomic characteristics } \\
\hline Gender (male) & $-0.229(0.173)$ & $-0.359 * *(0.139)$ & $-0.222(0.136)$ \\
\hline \multicolumn{4}{|l|}{ Age } \\
\hline $30-59$ years old & $-0.526 *(0.228)$ & $-0.167(0.172)$ & $-0.527 *(0.206)$ \\
\hline Over 60 & $-0.939 * *(0.277)$ & $-0.456 * *(0.222)$ & $-0.780 * *(0.229)$ \\
\hline \multicolumn{4}{|l|}{ Education } \\
\hline Secondary & $0.248(0.321)$ & $0.349(0.194)$ & $0.052(0.218)$ \\
\hline Higher & $-0.147(0.346)$ & $0.482 *(0.222)$ & $0.387(0.259)$ \\
\hline \multicolumn{4}{|l|}{ Region } \\
\hline South & - & - & $0.285(0.182)$ \\
\hline Left Bank & - & - & $0.607 *(0.272)$ \\
\hline Right Bank & - & - & $0.246(0.185)$ \\
\hline Centre & $0.604 * *(0.204)$ & - & - \\
\hline West/Europe ${ }^{a}$ & $0.538 *(0.215)$ & $0.003(0.150)$ & $10.172 * *(0.233)$ \\
\hline City resident & $-0.381(0.218)$ & $-0.433 *(0.173)$ & $-0.029(0.153)$ \\
\hline \multicolumn{4}{|l|}{ Income } \\
\hline Average & $-0.190(0.182)$ & $0.107(0.483)$ & $0.539 * *(0.139)$ \\
\hline High & $-0.307(0.365)$ & $0.204(0.670)$ & $0.281(0.352)$ \\
\hline \multicolumn{4}{|l|}{ Other determinants } \\
\hline \multicolumn{4}{|l|}{ Knowledge of EU } \\
\hline One answer correct & $0.437 *(0.215)$ & $0.322 *(0.163)$ & $0.005(0.156)$ \\
\hline Both answers correct & $0.703 * *(0.229)$ & $-0.039(0.188)$ & $0.069(0.185)$ \\
\hline \multicolumn{4}{|l|}{ European self-identity } \\
\hline Feel European & $0.776^{* *}(0.197)$ & $0.800 * *(0.163)$ & $10.187 * *(0.178)$ \\
\hline Neither & $-0.308(0.319)$ & $0.110(294)$ & $0.648 *(0.281)$ \\
\hline Constant & $10.61 * *(0.303)$ & $10.21 * *(0.303)$ & $0.690 *(0.333)$ \\
\hline \multicolumn{4}{|l|}{ Adj. R-sq. } \\
\hline Cox \& Snell & 0.28 & 0.21 & 0.27 \\
\hline Nagelkerke & 0.33 & 0.24 & 0.31 \\
\hline $\mathrm{Ns}$ & 1561 & 1956 & 1981 \\
\hline
\end{tabular}

Source: as Table 1 (2004 surveys).

Notes: $*$ statistically significant at $\mathrm{p}<0.05, * * \mathrm{p}<0.01$, both two-tailed. Standard errors are given in parentheses.

a : 'West' is used for Belarus and Ukraine; 'Europe' is used equivalently for Russia Variable codings and a further discussion are provided in the appendix. The dependent variable 'Support for EU membership' is scaled 1 =Approve, 2 = Neither, and 3=Disapprove'. In all three cases 'Disapprove' is used as the reference category. To save space the results for 'Neither' are not reported, but may be obtained from the authors on request. Gender and city residence are scaled $1=$ presence of the characteristic, $2=$ otherwise. Age is scored $1=$ over $60,2=30-59$ years old, $3=$ under 30 . Education is scored from $1=$ higher to $3=$ primary. Self-assessed income is scaled from $1=$ high to $3=$ low. The region variable is coded $1=$ European and $2=$ Asian in the case of Russia; $1=$ West, $2=$ Centre and $3=$ East in the case of Belarus; and $1=$ West, $2=$ South, $3=$ Left Bank, $4=$ Right Bank and $5=$ East in the case of Ukraine (we base these distinctions on Birch, 2000, p. 4). Knowledge of the EU is scored from $1=$ both answers correct to $3=$ none (for question wordings see Table 5). Finally, European self-identity takes values $1=$ feel European, 2 = neither, 3 = don't feel European. The high-ranking value within each scale for each variable is set at 0 when the regression analysis is performed, and therefore is not reported in Table 7. 
three countries. For instance, in all three countries being male was likely to be associated with opposition to membership, other things being equal, but only in Russia was it statistically significant. And as in our cross-tabulations, males were not only more likely to oppose EU membership, they were also more likely to support it; the difference was that those who opposed EU membership were more numerous than those who supported it - in Russia, for instance, males were 56 per cent of those who opposed membership, but 48 per cent of those who supported it. There was a similar effect for higher education in the case of Belarus; the negative sign of the coefficient for higher education in relation to support for EU membership indicates that levels of opposition were higher than levels of support among better-educated people. Only in Russia did the impact of education on the levels of support appear to be statistically significant, with a higher education likely to raise levels of support independently of other factors.

We sought to isolate the additional effects of region in this final stage of the analysis, on the assumption that a geographical closeness to the West would be likely of itself to increase levels of support for EU membership even after socioeconomic circumstances had been included in the model. Our assumptions were broadly confirmed: left-bank and still more so western Ukraine were significantly more likely to favour EU membership, other factors have been controlled for, but so too were the central and western regions of Belarus; in Russia it made little difference if our respondents lived in the European rather than the Asian part of the country. But taken as a whole, what is most striking is the limited explanatory power of all of these socioeconomic variables as compared with (for instance) 'feeling European' - a finding that is compatible with the literature on voting behaviour in these countries, which has generally concluded that the socioeconomic determinants that are dominant in Western countries are less important than political beliefs and attitudes (see for instance White et al., 1997, pp. 41-67).

\section{Conclusion}

It may be appropriate in conclusion to reiterate the limitations of this study. We have dealt with the three Slavic republics that were formerly part of the USSR and which among them account for three-quarters of the area and half the population of what was formerly communist-ruled Europe. But our conclusions should not be assumed to apply to the postcommunist world as a whole, indeed they were not always consistent across these three countries. Still less do we wish to suggest that the factors we identify are the 
starting-point in a causal sequence that has its only possible outcome in support for EU membership. 'Europe' is a social construct, defined as much in contradistinction to a 'non-Europe' as in more positive ways (see Neumann, 1999; van Ham, 2001; Splidsboel-Hansen, 2002), and we take identity to represent the outcome of this continuous negotiation of shared meaning not just by national populations but by subgroups and individuals within them. In this sense identities and attitudes towards the EU in particular are likely to reflect perceptions in the region of the posture of the EU and its member countries towards their wider 'neighbourhood' and whether the relationship is seen as 'inclusive' or 'exclusive': as a relationship in which much is shared (if not membership), or as a 'new dividing line' that takes on some of the significance of the East-West divisions of the cold war.

Issues of this kind, in turn, may not always be most fruitfully examined by a methodology that draws too heavily on the data that are generated by the EU itself, most obviously the Eurobarometer. Obviously, all such exercises raise issues of a kind that are familiar within crossnational survey research. But exercises that are conducted for the European Commission in order to extend its knowledge of the European Union are likely to deal with a restricted range of questions and to cover no more than the present membership of the Union together with the countries that are likely to join in the near future (they may also incorporate the unstated assumptions of the sponsoring organization, as Baycroft (2004, p. 154) has noted). The Central and Eastern Eurobarometer, which included the entire territory of the Russian Federation, was not extended beyond 1997. At the same time, the exercises that have been conducted on a pan-European basis - such as the European Social Survey - have not generally extended their scope to the post-Soviet republics, and have tended to overrepresent the richer and more developed countries that can more readily sustain the costs of taking part. ${ }^{2}$ We hope to have indicated another way forward, which is to focus on a group of countries that lie within geographical Europe but outside the scope of the barometer exercises that presently exist, while using question wordings that maximize a broader comparability.

Within this context, perhaps the central conclusion of this study is fluidity. There are broadly positive attitudes towards the EU and its member countries in Belarus, Russia and Ukraine, but also large elements of uncertainty. More than this, there are large elements of ignorance, compared not just with the existing EU Member States but also with a country such as Turkey, which is

\footnotetext{
${ }^{2}$ The European Social Survey, available at: «http://ess.nsd.uib.no», included no former Soviet republic in its first round but did include Estonia and Ukraine in its second round, conducted in 2004. Slomczynski and Tomescu-Dubrow identify three clusters, ranging from 'high participation in cross-national surveys' in the cases of the Czech Republic, Poland, Hungary and Slovenia, to 'low participation' in the cases of Albania, Moldova, Serbia, Macedonia, Bosnia and Croatia (2006, pp. 49-51).
} 
scarcely European in a geographical sense but which has been nominally seeking membership since 1963 and which has many of its citizens living and working in Germany and other parts of the continent. In these circumstances, the factors that shape support for membership are more likely to be attitudinal than social and economic; how could it be otherwise in a society in which forms of ownership have been changing rapidly and other certainties have been disappearing, in relation to a hypothetical development that has so far generated no winners or losers? 'Men make their own history', as Marx observes in the 18th Brumaire of Louis Napoleon (1852), 'but they do not make it just as they choose'. A new relationship between the two halves of 'Europe' will obviously reflect the socioeconomic environment in which both sides are located. But it will also reflect the negotiation of meaning between them in the ways we have examined in this article. This leaves a great deal of room for choices to be made by elites and publics across Member States and Slavic non-members about the different ways in which their relationship may be conceived.

\section{Correspondence:}

Stephen White

Department of Politics

University of Glasgow

Glasgow G12 8RT, UK

email s.white@socsci.gla.ac.uk

\section{Appendix}

Our surveys were conducted by Russian Research in association with the project on 'Inclusion without Membership? Bringing Russia, Ukraine and Belarus closer to "Europe", which is funded by the UK Economic and Social Research Council. In Russia, fieldwork took place between 21 December 2003 and 16 January 2004 and again between 23 March and 20 April 2005. The number of respondents in each case was 2000, selected according to the agency's normal sampling procedures; it was representative of the population aged 18 and over, using a multistage proportional method with a random route method of selecting households. Interviews were conducted face to face in respondents' homes. The sample was then weighted in accordance with sex, age and education in each region. In both cases there were 97 sampling points and 150 interviewers were employed; the agency's standard procedures were employed to check the completion of questionnaires and the logical consistency of the data. 
In Belarus, our survey was conducted under the auspices of the same agency between 27 March and 18 April 2004. The number of respondents was 1597 , selected according to the agency's normal sampling procedures; it was representative of the population aged 18 and over, using a multistage proportional representation method with a random route method of selecting households. Interviews were conducted face to face in respondents' homes. The sample was then weighted in accordance with sex and age in each region, using the 1999 census adjusted on the basis of expert estimates as of the start of 2003. There were 288 sampling points and 120 interviewers were employed; 10 per cent of the interviews were randomly selected for checking. Our 2006 survey was conducted on a similar basis by the Centre for Sociological and Political Research of the Belarusian State University between 5 and 19 June 2006, $\mathrm{n}=1000$.

In Ukraine, our survey was conducted under the auspices of Russian Research between 23 March and 2 April 2004. The number of respondents was 2000, selected according to the agency's normal sampling procedures; it was representative of the population aged 18 and over, using a multilevel, stratified method with a random method of selection at the final stage. Interviews were conducted face to face in respondents' homes. The sample was then weighted in accordance with sex and age in each region. There were 259 sampling points and 187 interviewers were employed; 10 per cent of the interviews were randomly selected for checking. Our 2006 survey was conducted by the same agency on similar principles between 24 April and 12 May 2006, $\mathrm{n}=1600$.

\section{References}

Allison, R., White, S. and Light, M. (2005) 'Belarus between East and West'. Journal of Communist Studies and Transition Politics, Vol. 21, No. 4, pp. 487511.

Allison, R., Light, M. and White, S. (2006) Putin's Russia and the Enlarged Europe (Oxford: Blackwell).

Antonenko, O. and Pinnick, K. (eds) (2005) Russia and the European Union: Prospects for a New Relationship (London: Routledge/IISS).

Baycroft, T. (2004) 'European Identity'. In Taylor, G. and Spencer, S. (eds) Social Identities: Multidisciplinary Approaches (London: Routledge).

Birch, S. (2000) Elections and Democratization in Ukraine (Basingstoke: Macmillan).

Borko, Y. and Danilov, D. (2005) Rossiya - Evropeiskii Soyuz: Strategiya Strategicheskogo Partnerstva (Moscow: Ogni).

Bruter, M. (2005) Citizens of Europe? The Emergence of a Mass European Identity (London: Palgrave). 
Buonanno, L. and Deakin, A. (2004) 'European Identity'. In Nugent, N. (ed.). European Union Enlargement (Basingstoke: Palgrave).

Butorina, O.V. and Borko, Yu.A. (eds) (2006) Rasshirenie Evropeiskogo Soyuza i Rossiya (Moscow: Delovaya Literatura).

Caplanova, A., Orviska, M. and Hudson, J. (2004) 'Eastern European Attitudes to Integration with Western Europe'. JCMS, Vol. 42, No. 2, pp. 271-87.

Cederman, L.-E. (2001) Constructing Europe's Identity: The External Dimension. (Boulder, CO: Lynne Rienner).

Commission of the European Communities (2004) European Neighbourhood Policy Strategy Paper (Brussels: European Commission).

Duchesne, S. and Frognier, A.-P. (1995) 'Is There a European Identity?' In

Niedemayer, O. and Sinnott, R. (eds) Public Opinion and Internationalized Governance (Oxford: Oxford University Press).

Duncan, Peter J.S. (2000) Russian Messianism: Third Rome, Holy Revolution, Communism and After (London: Routledge).

Eurobarometer (2005) Issue 62. Available at «http://europa.eu.int».

Eurobarometer (2006) Issue 64. Available at «http://europa.eu.int».

Glukharev, L.I. (ed.) (2006) Evropa Peremen: Kontseptsii i Strategii Integratsionnykh Protsessov (Moscow: Kvart).

Gujarati, D.H. (1995) Basic Econometrics (London: McGraw-Hill).

Haerpfer, C.W. (2002) Democracy and Enlargement in Post-Communist Europe (London: Routledge).

Hay, D. (1957) Europe: The Emergence of an Idea (Edinburgh: Edinburgh University Press).

Herrmann, R.K., Risse, T. and Brewer, M.B. (eds) (2004) Transnational Identities: Becoming European in the EU (Lanham, MD: Rowman and Littlefield).

Huntington, S.P. (1993) 'The Clash of Civilizations?' Foreign Affairs, Vol. 72, No. 3, pp. $22-49$.

Huntington, S.P. (1996) The Clash of Civilizations and the Remaking of World Order (London: Simon and Schuster).

Jacoby, W. (2005) The Enlargement of the European Union and NATO. Ordering from the Menu in Central Europe (Cambridge: Cambridge University Press).

Johnson, D. and Robinson, P. (eds) (2005) Perspectives on EU-Russia Relations (London: Routledge).

Litosseliti, L. (2003) Using Focus Groups in Research (London: Continuum). Miller, R.L. et al. (2002) SPSS for Social Scientists (Basingstoke: Palgrave).

Neumann, I.B. (1996) Russia and the Idea of Europe: A Study in Identity and International Relations (London: Routledge).

Neumann, I.B. (1999) Uses of the Other: 'The East' in European Identity Formation (Manchester: Manchester University Press).

Pagden, A. (ed.) (2002) The Idea of Europe: From Antiquity to the European Union. (Washington, DC: Woodrow Wilson Center Press). 
Slomczynski, K.M. and Tomescu-Dubrow, I. (2006) 'Representation of PostCommunist European Countries in Cross-National Public Opinion Surveys'. Problems of Post-Communism, Vol. 53, No. 4, pp. 42-52.

Smith, K.E. (2005) 'The Outsiders: The European Neighbourhood Policy'. International Affairs, Vol. 81, No. 4, pp. 757-74.

Snyder, T. (2003) The Reconstruction of Nations: Poland, Ukraine, Lithuania, Belarus, 1569-1999 (New Haven, CT: Yale University Press).

Splidsboel-Hansen, F. (2002) 'Russia's Relationship with the European Union: A Constructionist Cut'. International Politics, Vol. 39, No. 4, pp. 399-421.

Strath, B. (2002) 'A European Identity: To the Historical Limits of a Concept'. European Journal of Social Theory, Vol. 5, No. 4, pp. 387-401.

Timmins, G. and Gower, J. (eds) (2007) Russia and Europe in the Twenty-First Century: An Uneasy Partnership (London: Anthem Press).

Tucker, J.A., Pacek, A.C. and Berinsky, A.J. (2002) 'Transitional Winners and Losers: Attitudes towards EU Membership in Post-Communist Countries'. American Journal of Political Science, Vol. 46, No. 3, pp. 557-71.

Van Ham, P. (2001) 'Europe's Postmodern Identity: A Critical Appraisal'. International Politics, Vol. 38, No. 2, pp. 229-52.

White, S., Rose, R. and McAllister, I. (1997) How Russia Votes (Chatham House, NJ: Chatham House).

Wilson, A. (2000) The Ukrainians: Unexpected Nation, 2nd edn (New Haven, CT: Yale University Press).

Wolff, L. (1994) Inventing Eastern Europe: the Map of Civilization on the Mind of the Enlightenment (Stanford, CA: Stanford University Press). 